\title{
Can varying the number of teams in a shift schedule constitute a preventive strategy?
}

\author{
Hans Jeppe Jeppesen ${ }^{a}$, Magnar Kleiven ${ }^{b}$ and Henrik Bøggildc \\ ${ }^{a}$ D epartment of Psychology. U niversity of Aarhus. Denmark. ${ }^{b}$ Confederation of N orwegian Business \\ and Industry. Oslo, Norway. 'D epartment of O ccupational Medicine. Aalborg Hospital. University \\ Hospital of Aarhus. Denmark
}

\section{Keywords}

Shift work. Workers. Organization and administration. Work hours. Job satisfaction.

\begin{abstract}
Objective

The study examines the implications for shiftworkers of applying different numbers of teams in the organization of shiftwork.

Methods

The participating operators came from five different companies applying continuous shift rotation systems. The companies shared the same product organization and a common corporate culture belonging to the same multinational company. Each company had a shift system consisting of four, five or six teams, with the proportion of shifts outside day work decreasing as the number of teams increased. Questionnaire and documentary data were used as data sources.

Results

Operators in systems with additional teams had more daywork but also more irregular working hours due to both overtime and schedule changes. Operators using six teams used fewer social compensation strategies. Operators in four teams were most satisfied with their work hours. Satisfaction with the time available for various social activities outside work varied inconsistently between the groups.

Conclusions

In rotating systems the application of more teams reduces the number of shifts outside day work. This apparent improvement for shiftworkers was counteracted by a concomitant irregularity produced by greater organizational requirements for flexibility. The balance of this interaction was found to have a critical impact on employees.
\end{abstract}

\section{Descritores}

Trabalho em turnos. Trabalhadores. Organização e administração. Jornada de trabalho. Satisfação no trabalho.

\section{Resumo}

\section{Objetivo}

Investigar as implicações para trabalhadores em turnos do uso de um número distinto de turmas de trabalho na organização dos turnos.

\section{Métodos}

Participaram do estudo operadores de cinco empresas que usavam sistemas contínuos de turnos alternantes. As empresas tinham em comum a organização de produtos $e$ cultura empresarial e pertenciam a uma mesma empresa multinacional. Cada uma das empresas tinha um sistema de turnos que compreendia quatro, cinco ou seis turmas de trabalho, sendo que a proporção de turnos fora dos horários diurnos

\footnotetext{
Correspondence to:

Hans Jeppe Jeppesen

Department of Psychology, University of Aarhus

Nobelparken, Jens Chr. Skous Vej 4

DK 8000 Aarhus C, Denmark

E-mail: jeppe@psy.au.dk
}

Presented at the XVI International Symposium on N ight and Shiftwork, N ovember 2003. Santos, SP, Brazil.

This study was financed through grants from N orsk Hydro Research Foundation (n. 0398) and from The Work Environmental Fund of the Confederation of N orwegian Business and Industry (n. 1328)

Received on 15/3/2004. Approved on 27/9/2004 
diminuía à medida que aumentava o número de turmas. Foram usados dados de questionários e documentação como fontes de pesquisa.

\section{Resultados}

Os operadores de sistemas com turmas extras apresentaram uma quantidade maior de trabalho diurno, assim como mais horas irregulares de trabalho em decorrência de horas extras e mudanças de horário. Os operadores que contavam com seis turmas usaram menos recursos de compensação social. Os que trabalharam com quatro turmas ficaram mais satisfeitos com os horários de trabalho. A satisfação com o tempo disponível para diversas atividades sociais fora do trabalho variou de modo inconsistente entre as turmas estudadas.

Conclusões

Nos sistemas com turnos rodiziantes, o uso de um número maior de turmas reduz o número de turnos não-diurnos. Esta aparente vantagem aos trabalhadores em turnos foi neutralizada pela concomitante irregularidade resultante de maiores exigências organizacionais para permitir flexibilidade. Verificou-se que o equilíbrio desta interação teve um impacto fundamental sobre os trabalhadores.

\section{INTRODUCTION}

The organization of working time can be regarded as a process requiring resolution of various tensions, considerations and interests. The temporal structure of shiftwork interferes with both the prevailing time patterns of society and biological circadian rhythms. This disharmony imposes limitations on the social activities of shiftworkers and disruption to physiological and psychological functions ${ }^{23}$ that may cause impairment of shiftworkers' social and family life, reduced well-being, increased risk of sickness and accidents., ${ }^{5,21}$ These outcomes are influenced by, amongst other things, the design of shift schedules and interactions between other working conditions, family structures and personal interests. ${ }^{14,15}$ Moreover, perceived advantages from shiftwork may not counterbalance disadvantages for health. ${ }^{19}$ The effects of shiftwork are connected to the way it is organized and designed, for example by factors such as speed of rotation, shift duration and the distribution of free time. ${ }^{10}$ Employee participation in designing shiftwork also influences its effects and is important in creating more congruence between shiftwork and the employees' needs and preferences. ${ }^{9}$ The aim of health and safety regulation is thus also to change exposure by framing requirements for shift schedule design. ${ }^{7}$

The use of additional teams in shift schedules may form part of a strategy to adjust to market demands by strengthening production flexibility and increasing functional flexibility through internal training and competence development. The introduction of additional teams typically takes place without new appointments but through transfers from other teams. This approach implies fewer persons in each team to respond to changes in production demands and unexpected situations. At the same time it may involve changes in work schedules with fewer evening and night shifts and more day shifts, including training days, for individual shiftworkers.

This cross sectional study investigates the impact of different numbers of teams on both shiftwork organization and shiftworkers. The possibility that increasing the number of teams reduces the adverse effects of shiftwork is examined. No previous comparable studies of the effects of applying different numbers of teams have been identified.

\section{METHODS}

The study presented here was part of a larger European project conducted in local companies in different countries that investigated the importance of employee participation in the organization of shiftwork. The participating companies belonged to the same Norwegian multinational company, Norsk Hydro; all, except one, produced fertilizers. They were part of the same division and shared a common corporate culture, but acted as independent entities. They shared much of the same technology and product organization and were of fairly comparable sizes, ranging from 145 to 729 employees, although the largest ones were divided into subunits. A general reduction in the workforce at each company had taken place during the preceding decade and had been particularly extensive in Germany. The companies were unionised and had continuous production. In the larger study the data sources consisted of documentary material, semi-structured interviews and questionnaires.

\section{Participants}

The participants were selected from companies that participated in the questionnaire research and had 
continuous rotating shift systems. The companies were Ferrara (Italy), Rostock (Germany), Sluiskil (the Netherlands), Porsgrunn (Norway) and Köping (Sweden). They operated shift schedules with four, five or six teams but attended only to one of the types in production, except for special arrangements in shipments. Using the questionnaire items about work role and current working hours it was possible to identify all operators working within, outside or both within and outside the control room at each company. Operators constituted most of the rotating shiftworkers. In identifying the participants for this study the number of operators were double checked by comparing their stated work role with their replies regarding their work schedules. Details of sample characteristics across the five companies are shown in Table 1.

\section{Questionnaire}

The questionnaire was primarily designed to give information about attitudes, working time and social life. Data on these matters should assist in developing strategies for preventive design of shift schedules. The study was not initiated in order to identify health risks associated with the different schedules.

The questionnaire included items about social and work demographic variables and different working time dimensions including extra working hours and changes in the planned schedules during the preceding four weeks. The questionnaire also included items concerning influence over, and satisfaction with, working hours, preferences to change to day work, and the interaction between working hours and social life. Items were assessed on five-point scales that ranged from no importance to very important, none to com- pletely, or agree strongly to disagree strongly. This paper deals with the organization of shiftwork and associated processes at the structural level and data on individual preferences regarding the design of schedules are not examined here. However, scales from Standard Shiftwork Index ${ }^{2}$ were used to investigate sleep quality. Vitality and mental health were also measured using two subscales (consisting of five and four items respectively) from the SF $36 .^{3}$ Finally a revised overall job satisfaction scale ${ }^{20}$ consisting of 20 items about work dimensions, was used. It employed a seven-point response scale ranging from very dissatisfied to very satisfied.

The questionnaires were distributed by the local project groups and returned anonymously to employee representatives who passed them on to the researchers.

\section{Shift schedules}

Information about shift schedules was collected from each company. Table 2 describes some features of the schedules. Different characteristics, such as meeting time, length of weekend shifts, and speed and direction of rotation appear to vary independently of the number of teams. A weekend off is defined as extending from the end of Friday afternoon shift until Monday morning shift. In counting the longest consecutive work period only production days are included.

For dimensions directly connected to the number of teams, such as number of different shift and days off, the largest differences can be found between teams of 4 and 6 , with 5-member teams in between. How-

Table 1 - Participants divided into number of teams and operators.

\begin{tabular}{|c|c|c|c|c|c|c|}
\hline Company & $\begin{array}{c}\text { No. of } \\
\text { workers } \\
\text { on night shift }\end{array}$ & $\begin{array}{c}\text { No. of } \\
\text { participants }\end{array}$ & $\begin{array}{c}\text { Response } \\
\text { rate } \\
(\%)\end{array}$ & $\begin{array}{c}\text { No. of } \\
\text { operators } \\
\text { with four teams }\end{array}$ & $\begin{array}{c}\text { No. of } \\
\text { operators } \\
\text { with five teams }\end{array}$ & $\begin{array}{c}\text { No. of } \\
\text { operators } \\
\text { with six teams }\end{array}$ \\
\hline $\begin{array}{l}\text { Ferrara (I) } \\
\text { Köping (S) } \\
\text { Porsgrunn (N) } \\
\text { Rostock (G) } \\
\text { Sluiskil (NL) }\end{array}$ & $\begin{array}{c}74 \\
69 \\
180 \\
129 \\
287\end{array}$ & $\begin{array}{c}38 \\
41 \\
72 \\
59 \\
159\end{array}$ & $\begin{array}{l}51 \\
59 \\
40 \\
46 \\
55\end{array}$ & 36 & 29 & $\begin{array}{l}27 \\
53\end{array}$ \\
\hline
\end{tabular}

Table 2 - Features of the shift schedule at each participating company.

\begin{tabular}{|c|c|c|c|c|c|c|c|c|c|c|c|}
\hline & $\begin{aligned} D \\
\text { Morning }\end{aligned}$ & $\begin{array}{l}\text { uration of } \\
\text { Evening }\end{array}$ & $\begin{array}{c}\text { shifts (h } \\
\text { Night }\end{array}$ & $\begin{array}{l}\text { urs) M } \\
\text { Week } \\
\text { ends }\end{array}$ & $\begin{array}{l}\text { of co } \\
\text { All } \\
\text { type } \\
\text { of } \\
\text { shifts }\end{array}$ & $\begin{array}{c}\text { secutive } \\
\text { Night } \\
\text { shifts }\end{array}$ & $\begin{array}{l}\text { shifts } \\
\text { Introduction } \\
\text { of the } \\
\text { shift } \\
\text { schedule }\end{array}$ & $\begin{array}{c}\text { Direction } \\
\text { of } \\
\text { rotation }\end{array}$ & $\begin{array}{c}\text { Week } \\
\text { ends } \\
\text { off }\end{array}$ & $\begin{array}{c}\text { Start } \\
\text { morning } \\
\text { shift }\end{array}$ & $\begin{array}{c}\text { Max. } \\
\text { days in } \\
\text { off-duty } \\
\text { sequence }\end{array}$ \\
\hline $\begin{array}{l}\text { Ferrara (5 teams) } \\
\text { Køping ( } 6 \text { teams) } \\
\text { Porsgrunn ( } 6 \text { teams) } \\
\text { Rostock ( } 4 \text { teams) } \\
\text { Sluiskil (5 teams) }\end{array}$ & $\begin{array}{l}8 \\
8 \\
8 \\
8 \\
8\end{array}$ & $\begin{array}{l}8 \\
8 \\
8 \\
8 \\
8\end{array}$ & $\begin{array}{l}8 \\
8 \\
8 \\
8 \\
8\end{array}$ & $\begin{array}{c}8 \\
12 \\
12 \\
12 \\
8\end{array}$ & $\begin{array}{l}2 \\
5 \\
5 \\
7 \\
4\end{array}$ & $\begin{array}{l}2 \\
4 \\
2 \\
7 \\
4\end{array}$ & $\begin{array}{l}1989 \mathrm{Cc} \\
1996 \\
1992 \\
1984 \\
1990 \mathrm{Cc}\end{array}$ & $\begin{array}{c}\text { Counter-clockwise } \\
\text { Clockwise } \\
\text { Clockwise } \\
\text { Clockwise } \\
\text { Counter-clockwise }\end{array}$ & $\begin{array}{l}2 \text { of } 5 \\
4 \text { of } 6 \\
4 \text { of } 6 \\
3 \text { of } 6 \\
2 \text { of } 5\end{array}$ & $\begin{array}{l}06.00 \\
06.00 \\
05.30 \\
05.15 \\
06.00\end{array}$ & $\begin{array}{l}2 \\
5 \\
5 \\
5 \\
3\end{array}$ \\
\hline
\end{tabular}


ever, weekly work hours and compensations for shiftwork are also related to these dimensions. Collectively agreed normal weekly hours in the chemical industry at the time of data collection were: Sweden 40, former East Germany 39.2, Netherlands 39, Italy 37.8 and Norway 37.5. ${ }^{6}$ Shiftwork compensation was provided through either financial rewards or reduced weekly work hours, or a combination of both. From the figures on weekly work hours it appears that they were independent of the number of teams, with Sweden at the top and Norway at the bottom.

The work schedules for Germany, the Netherlands and Sweden (with four, five and six teams respectively) were compared over a 12 -week period. These three countries had the highest weekly work hours and were therefore the most directly comparable. The schedule from Germany with 4 teams consisted of 21 day shifts, 15 afternoon shifts, 21 night shifts and 27 days off in 84 days. The shift cycle was 28 days. The schedule from the Netherlands consisted of 17 day shifts, 17 afternoon shifts, 17 night shifts and 33 day days off. The shift cycle was 35 days. The Swedish schedule had 24 day shifts (including 14 days for training etc.) 10 afternoon shifts, 14 night shifts and 36 days off in 84 days. The shift cycle was 42 days. The differences between the number of afternoon and night shifts in the German and Swedish schedules were determined by the fact that the weekend shifts were 12 hours. In comparing the German and Swedish schedules the variations in number of days off illustrate differences between financial compensation and reduction in working hours, as the difference in the formally agreed weekly hours is less than one hour. The internal distribution between type of shifts shows the effects of applying different numbers of teams.

No differences in individual flexibility were associated with the different schedules. The organization of shiftwork, including the number of teams, was based on production considerations and control was solely the prerogative of the companies.

\section{Analyses}

The following analyses compared the schedules using four, five or six teams on single items and composite scales. The analyses were performed at the group level, as the aim of the research was to identify differences arising from overall shiftwork organization and administration of schedules. In comparisons based on frequency data, Pearson's chi-square test was used, and in comparisons based on ordinal dependent variables the non-parametric Wilcoxon, MannWhitney and Kruskal-Wallis tests were used.

\section{RESU LTS}

\section{The participants}

The operators working on continuous shiftwork in the five participating companies were almost all (97\%) male. There were differences $(\mathrm{p}=0.004)$ in the age distribution between the three groups. The group with 5 teams was the eldest (medians were 37.5, 42.0, 37.0 and interquartile ranges were10.5, 13.0, 10.0 respectively for the groups with four, five and six teams). The variations in age were also reflected in seniority. The group with six teams had the lowest seniority $(p=0.013)$, and it was slightly higher for the group with four teams than the one with five. No differences in marital status or the number of children living at home were found between the groups.

There were no significant differences between the groups in distribution of operators working within, outside, or both within and outside control room. There were also no differences in number of participants handling representative tasks between the groups. There were, however, significant differences $(\mathrm{p}=0.008)$ in the number handling leadership tasks. There were significantly fewer persons in companies with six teams compared to the two others, but no differences between four and five teams, which may indicate the importance of cultural and contextual factors in interpreting leadership tasks.

\section{Working hours}

Management of shiftwork and schedule design by the five companies, which represented organizationally-controlled flexibility, was investigated by asking

Table 3 - Distribution of extra working hours and changes in work schedules during the preceding four weeks.

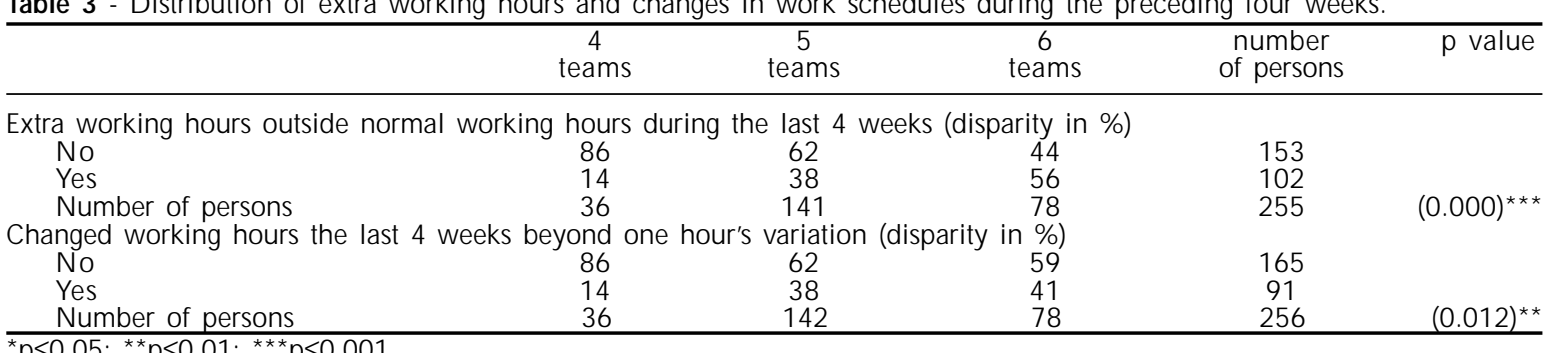


about extra working hours and changes in scheduled working hours during the four weeks prior to the completion of the questionnaire. The results in Table 3 show pronounced differences between companies with 4, 5 and 6 teams. The number of changes and extra hours both increased as the number of teams increased.

Individual shiftworkers' perceptions of influence over the working hour arrangement varied significantly $(p=0.000)$. On a five point Likert scale ranging from none (1) to completely influence (5) the medians for the groups with four, five and six teams were 1,2 , and 2 respectively and associated interquartile ranges were $0.5,1$, and 2. Differences in employee influence between the participating companies were larger, with most influence apparent in companies using 6 teams ( $\mathrm{p}<0.001)$. The medians were 1 , 2 and 3 and respectively for four, five and six teams and the interquartile ranges were 1,1 and 1 .

\section{Work attitudes}

No statistical differences $(\mathrm{p}=0.096)$ in satisfaction with working hours were found (median 3, 3, 3 and interquartile ranges $1,1,0)$. Satisfaction with the shift system was further investigated through two items about preferences to the change from shiftwork to daywork, with or without financial compensation. For changing without compensation a significant difference (0.002) was seen between the groups. Employees in shift systems with six teams were less likely to wish to change and more unsure than for systems with four or five teams. The answers for the other two groups were not significantly different. The distribu- tion of answers to the item about changing with compensation also showed differences $(p=0.004)$ between the groups and in all three groups there was a similar large increase in the number of people who now preferred to change. About $75 \%$ of the employees in shift systems with four and five teams and a little more than $50 \%$ of those in six teams stated that they would prefer to change. There was still a group of persons especially amongst those in six teams $(29 \%)$ - who did not wish to change their working hours, and the smallest group was employees in doubt.

For the 20-item overall job satisfaction scale, there were no differences $(p=0.44)$ between the groups. The medians of the 4, 5 and 6 team groups were 68,78 , and 75 respectively and the associated interquartile ranges were 24, 29, and 23 .

\section{Social conditions and well-being}

Demands on life outside work were investigated in six questions using a five points Likert reply scale. The analysis of these items is shown in the Table 4 . Regardless of the number of teams in the shift system, half or more of the shiftworkers reported having taken steps to adapt other aspects of their lives to their working hours.

Social effects were further investigated through questions about time available for different types of activities. The results are presented in Table 5. In relation to both activities performed together with others and formalized organizational activities, available social time was reported to be insufficient.

Table 4 - Changes in non-work activities in response to working hours by number of teams.

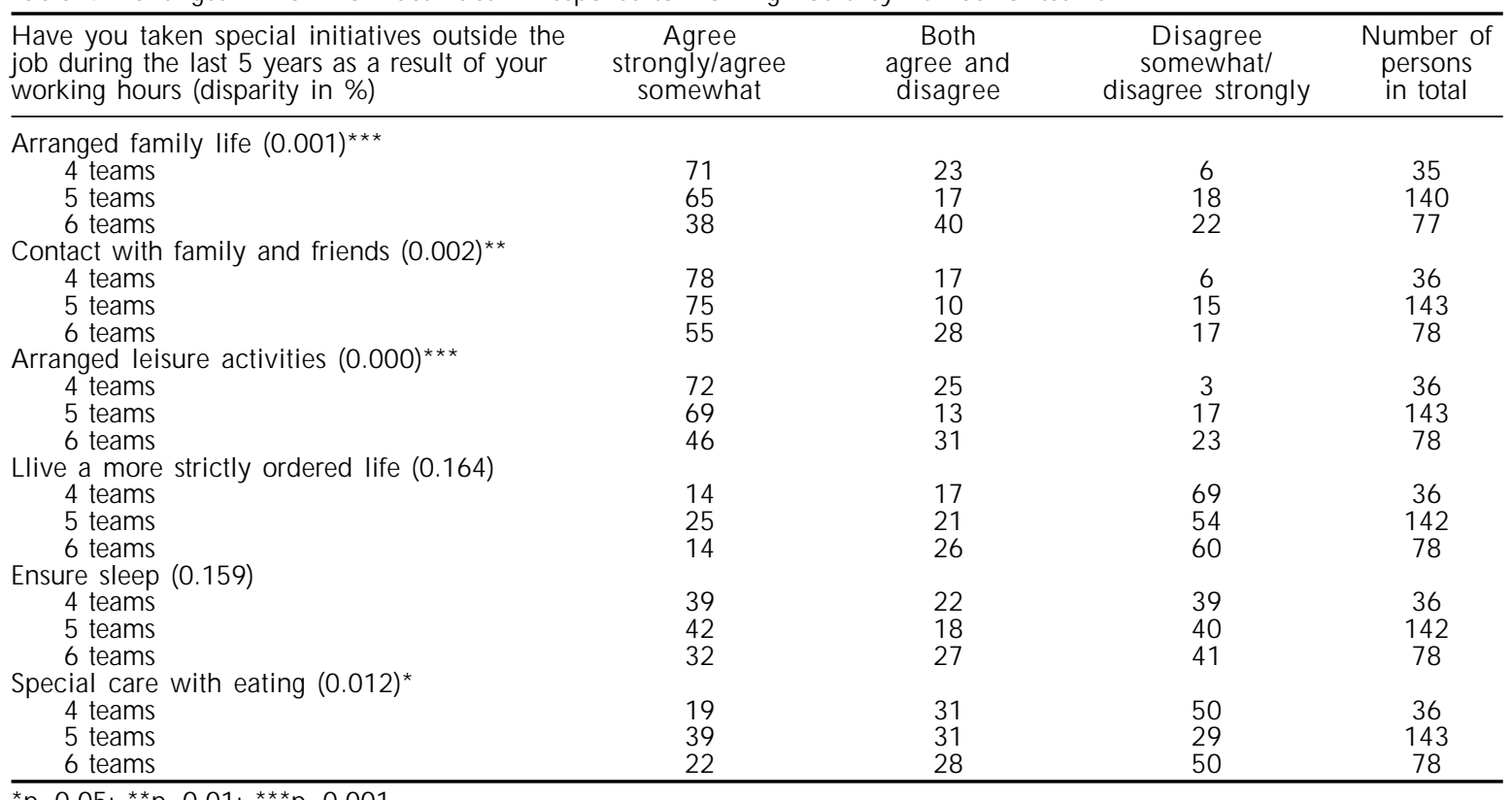


Table 5 - Satisfaction with time for non-work activities by number of teams.

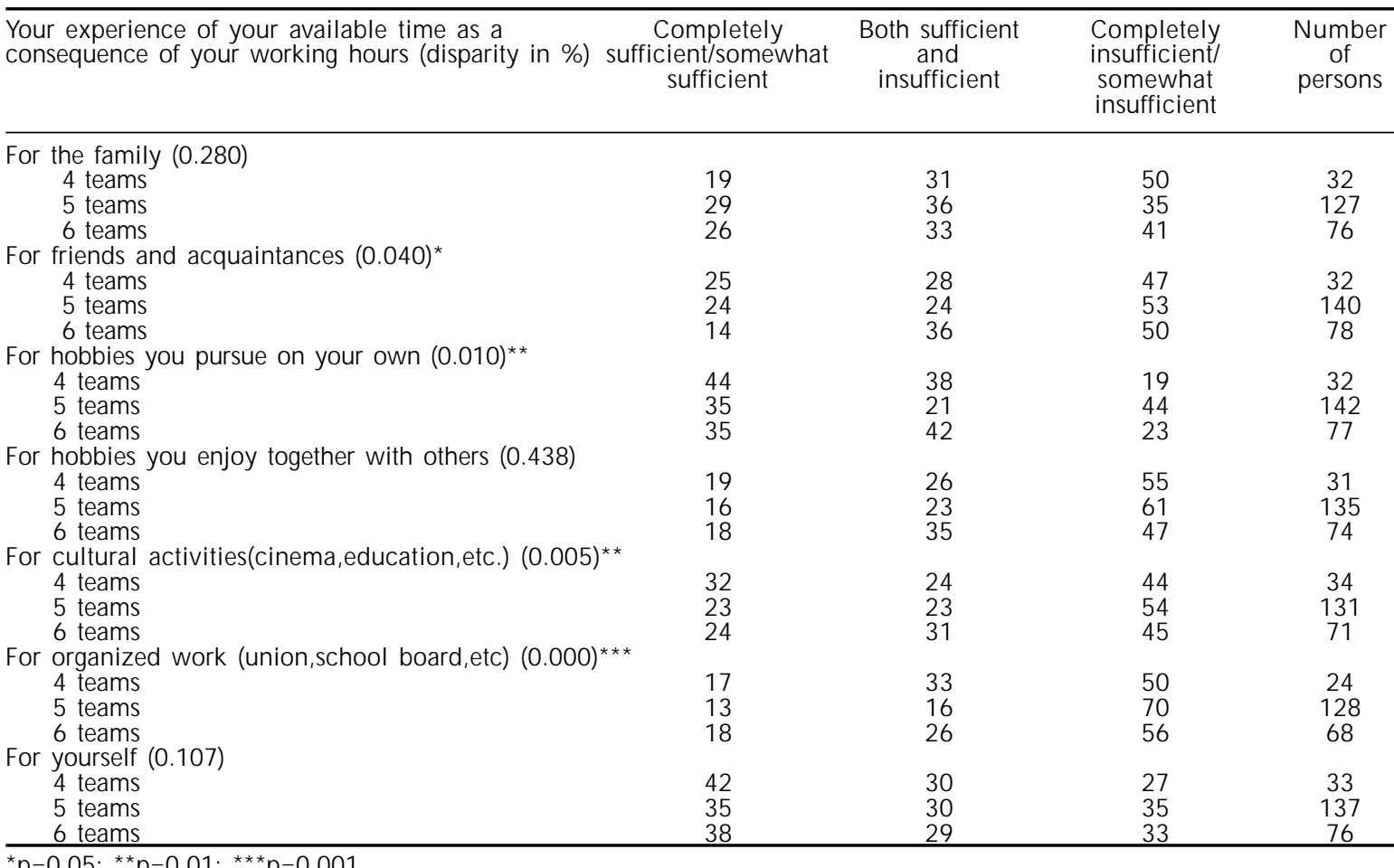

$* p=0.05 ; * * p=0.01 ; * * * p=0.001$

Sleep was investigated by examining the quality of sleep between day shifts, between evening shifts, between night shifts and between days off. The analyses here revealed no differences between the three groups in sleep quality for day shift, afternoon shift and night shift. For sleep between days off, employees in systems with five teams reported lower sleep quality (median 18.5, 18 and 19; interquartile range 2, 2, 2; $\mathrm{p}=0.001$ ) than employees in the other systems.

The interplay between shift system and health was investigated at three different levels. In a single question about health in general no differences were found $(\mathrm{p}=0.292$ ). Energy level (or vitality) was measured with a 4-item scale relating experience over the preceding four weeks. Replies were based on frequency. No significant differences $(\mathrm{p}=0.068)$ were found (median 11, 13, 12 and interquartile range 5, 5, 6). Mental health was measured on a scale consisting of five items concerning emotional states over the preceding four weeks. Responses were based on frequency. No significant differences $(\mathrm{p}=0.333$ ) were found between the systems (medians were 11, 12, 10 and interquartile ranges were $5,6,7$ ).

\section{DISCUSSION}

The participating companies introduced more teams in their shift schedules to improve adaptation to fluctuating market demands and to develop employee competencies. For example, in the full six- weeks rotation cycle for six teams one week was formally set aside for education and training. However, the introduction of more teams was made through the transfer of workers from existing teams rather than taking on new employees.

The analyses of the different shift systems show that increasing the number of teams in continuous shiftwork may offer opportunities for designing shift systems with a reduced number of shifts outside day work and with an increased number of weekends off. As the number of shiftworkers was not increased, the increase in the number of teams constituted an organizational flexibility strategy to respond to fluctuating external and internal demands. This study shows that an increased number of teams was associated with an increase in irregularity and unpredictability of working hours. It is assumed that the mixed responses to the survey reflect the effects of these divergent tendencies on work attitudes, health and social life.

The interpretation of the results may be affected by some limitations. The study was a cross sectional study, which means that it was particularly sensitive to secondary health selection. Downsizing had occurred to some extent in all companies, with the largest reduction in the workforce occurring at Rostock. However, there was no evidence of differences in selection. In a cross-national study of this nature, social life and shiftwork cultures may have varied but the results identified no systematic differences between the shiftwork- 
ers apart from differences in number of teams in their shift schedules. Furthermore, the companies had very comparable working conditions and work functions irrespective of differences in the number of teams and country. Response rates were also similar in all the participating companies and across the 4-, 5- and 6team groups. The results could also have been biased by differences in workers' control over working hours. However, this is unlikely since in all cases the companies controlled flexibility and no formal policies for individual flexibility existed.

The importance of national differences in work relations concerning employee participation is probably reduced in this study as all companies belong to the same multinational company and take part in the same European Work Council with representatives from each company. Furthermore, the ongoing development of EU labour regulations concerning working time and the management of health and safety also reduced the importance of national differences in work relations.

However, national differences did find expression in the variations in the weekly working hours and compensations methods for shiftwork. This influenced the conditions for organizing shiftwork but it was not consistently related to the number of teams, as Rostock with four teams and Köping with six teams had the highest number of weekly working hours. The analyses of the shift schedules revealed further that differences in the number of shifts outside daywork cannot be explained by the number of teams alone but are also determined by other dimensions. Thus Table 2 illustrates differences independent of the number of teams, such as 12-hour weekend shifts, different directions of rotation and variations in the number of consecutive days off. In this study the systems with four and six teams are more equal on these dimensions than systems with five teams. Analyses of changes in the planned schedules show that shiftworkers from systems with six teams reported the highest number of changes, followed by systems with five teams and the lowest number of changes in systems with four teams. These findings suggest it is most accurate to conclude that this study investigates three different shift schedules consisting of different charateristics that are associated with the number of teams and other factors.

The schedules can be differentiated from each other by the number of shifts outside daywork and by irregularity caused by changes in the planned schedules. In this way the system with four teams can be categorized as having the highest number of shifts outside day work and the highest level of regularity, whereas systems with five teams had only a slightly smaller number of shifts outside day work but considerably less regularity. Systems with six teams were characterized by the smallest number of shifts outside day shift and the lowest regularity. As the different dimensions of a schedule are mutually connected and changes in one dimension are followed by changes in other dimensions, differences on particular dimensions may also interact. How to establish the accurate categories of analysis concerning alterations of shift schedules is an ongoing question in shiftwork research.

No previous studies have been performed on the effects of different numbers of teams, which implies that comparison to other studies has to be drawn in terms of characteristics such as regularity, number of shifts outside day work and flexibility control. Fewer shifts outside standard day shifts should imply a reduction in the strain from shiftwork via improved social conditions and less readjustments of biological rhythms. ${ }^{5,16}$ A switch from systems with night shifts to systems without night shifts increased social wellbeing and improved work attitudes in an experimental study. ${ }^{22}$ Improvement on biomarkers of heart disease have been reported after introducing greater regularity and more weekends off together with fewer consecutive nights and only two different types of shifts. ${ }^{4}$ Increased need for recovery has also been demonstrated among irregular shiftworkers. ${ }^{8}$ Positive effects on social life have been shown after conversion to a 12-h shift schedule involving more days off but differences in adaptation among the participants were also noted. ${ }^{1}$ Control over working time is reported to be a significant factor affecting the impact of a rota ${ }^{13,17}$ and participation has been found to be important in creating a win-win situation. ${ }^{18}$ Negative effects on satisfaction from no autonomy have also been noted. ${ }^{12}$ Research can thus be assumed to confirm that fewer shifts outside day work, regularity and employee participation reduce the adverse effects of shiftwork.

In this study, shiftworkers in systems with fewer teams had in general taken more initiatives with respect to social activities to avoid conflicts than shiftworkers in systems with more teams, particularly six teams. This supports the findings regarding the benefits of a reduced number of non-day shifts for social functioning reported in the studies cited above. Although all respondents reported that available social time was not sufficient, irrespective of number of teams, this problem was most pronounced for shiftworkers in five teams. This result may reflect the fact that employees in five-team schedules were considerably more likely to experience changes in planned schedules than those in four-team schedules, but did not have the reduced number of shifts outside daytime enjoyed by those working in six teams. 
No differences were uncovered between the groups concerning sleep and well-being. This should be expected from the reduction in non day shifts but not from an increase in irregularity. However, it should be noted that the measures used for vitality and mental state simply may be more responsive to the shiftworker's position in the shift cycle than the total strain from the schedule.

No differences were found in general job satisfaction or satisfaction with working hours. As employees in four teams reported significantly lower individual and group influence on the design of the working hours, these results appear to conflict with results from other studies. ${ }^{13,17}$ An explanation may be that perceived influence relates to the design of the schedule and not to the daily management of the working hours. The results indicate that the level of satisfaction at least in part derives from the daily management of the schedules and the importance of this may be extended by increased differences between influence on design and management. Such a difference is more likely to turn up when daily management is aimed at organizational rather than individual flexibility. These considerations point to the importance of understanding the influence of context on the findings.

\section{CONCLUSIONS}

This exploratory study produced new information about the effects of variations in the number of teams in shift schedules. Operating with four, five or six teams offers different possibilities for schedule design. In rotating systems a recurrent feature was that using more teams reduced the number of shifts outside day work. The apparent benefits for shiftworkers were counteracted by a concomitant increase in schedule irregularity. This irregularity resulted from increased organizational requirements for flexibility from individual shiftworkers because increases in the number of teams were achieved by transferring workers from existing teams rather than making new appointments. How this interaction is balanced was found to exert a critical influence over the impact on employees of more teams in the shift schedule. Studies of long-term effects are now necessary. The present results suggest that future research in shiftwork incorporate consideration of the daily management of the schedules as an independent variable.

\section{ACKNO WLED G EMENT}

We wish to thank the employees and the managers from the participating companies for their cooperation and also the involved staff from Norsk Hydro.

\section{REFEREN CES}

1. Aguirre A, Heitmann A, Imrie A, Sirois W, Moore-Ede $M$. Conversion from an 8-h to a 12-h shift schedule. In: Hornberger S, Knauth P, Costa G, Folkard S. Shiftwork in the $21^{\text {st }}$ century: challenges for research and practice. Frankfurt :Peter Lang; 2000. p. 113-8. (Arbeitswissenschaft in der betrieblichen Praxis, 17).

2. Barton J, Spelten E, Totterdell P, Smith L, Folkard S, Costa G. The standard shiftwork index: a battery of questionnaires for assessing shiftwork-related problems. Work Stress 1995;9:4-30.

3. Bjørner JB, Damsgaard MT, Watt $T$, Bech $P$, Rasmussen NK, Kristensen TS, Modvig J, Thurnedborg K. Danish manual for SF-36. Copenhagen: Lif; 1997.

4. Bøggild $H$, Jeppesen $H J$. Intervention in shift scheduling and changes in biomarkers of heart disease in hospital wards. Scand J Work Environ Health 2001;27:87-96.

5. Costa G. The problem: shiftwork. Chronobiol Int 1997;14:89-98.
6. [EIRO nline] European Industrial Relations O bservatory on-line. Working time developments annual update 2000. Dublin: European Foundation for the Improvement of Living and Working Conditions; 2001. p. 1-21.

7. European Commission. Council Directive 93/104/EC of 23 November 1993 concerning certain aspects of the organization of working time. Brussels; 1993.

8. Jansen NWH, Kant I, van Amelsvoort LGPM, Nijhuis FJN, van den Brandt PA. Need for recovery from work: evaluating short-term effects of working hours, patterns and schedules. Ergonomics 2003;46:664-80.

9. Jeppesen HJ. Participatory approaches to strategy and research in shiftwork intervention. Theor Issues Ergon Sci 2003;4:289-301.

10. Knauth P. Designing better shift systems. Appl Ergon 1996;27:39-44.

11. Knauth P. Changing schedules: shiftwork. Chronobiol Int 1997;14:159-71. 
12. Knauth P. Innovative worktime arrangements. Scand J Work Environ Health 1998;24(Suppl 3):13-7

13. Krausz M, Bidermann Y. Actual and preferred work schedules and scheduling control as determinants of job-related attitudes. J Vocat Behav 2000;56:1-11.

14. Loudoun RJ, Bohle PL. Work/non-work conflict and health in shiftwork: relationships with family status and social support. Int I O ccup Environ Health 1997;3(Suppl 3):71-7.

15. Nachreiner F. Individual and social determinants of shiftwork tolerance. Scand J Work Environ Health1998;Suppl 3:35-42.

16. Scott AJ, Ladou J. Shiftwork: effects on sleep and health with recommendations for medical surveillance and screening. Occup Med 1990;5:273-99.

17. Smith L, Hammond T, Macdonald SF. 12-h shifts are popular but are they a solution? Int J Ind Ergon $1998 ; 21: 323-31$
18. Smith PA, Wedderburn AAI. Flexibility and long shifts Employee Relat 1998;20:483-9.

19. Taylor E, Folkard S, Shapiro DA. Shiftwork advantages as predictors of health. Int J Occup Environ Health 1997;3(Suppl 3):20-9.

20. Warr PB, Cook J, Wall TD. Scales for the measurement of some work attitudes and aspects of psychological well-being. J Occup Psychol $1979 ; 52: 129-48$

21. Wedderburn A. Shiftwork and health. Dublin: European Foundation for the Improvement of Living and Working Conditions; 2001. ( BEST - Bulletin of European Stud Time, 1).

22. Åkerstedt T, Torsvall L. Experimental changes in shift schedules - their effects on well-being. Ergonomics $1978 ; 21(10): 849-56$

23. Akerstedt T. Psychological and psychophysiological effects of shiftwork. Scand J Work Environ Health 1990;16(Suppl 1):67-73. 